\title{
ANALIZA WSKAZAŃ DO I OCENA WYNIKÓW PO WTÓRNYCH OPERACJACH PO PIERWOTNYM ZAOPATRZENIU URAZÓW W OBRĘBIE KOŃCZYNY GÓRNEJ
}

\author{
AN ANALYSIS OF THE INDICATIONS FOR, AND ASSESSMENT \\ OF THE OUTCOMES OF SECONDARY SURGERY AFTER PRIMARY REPAIR \\ OF INJURIES WITHIN THE UPPER LIMB
}

\author{
Klinika Chirurgii Ogólnej i Chirurgii Ręki Pomorskiego Uniwersytetu Medycznego w Szczecinie \\ ul. Unii Lubelskiej 1, 71-252 Szczecin \\ Kierownik: prof. dr hab. n. med. Andrzej Żyluk
}

\begin{abstract}
Summary
Introduction: The objective of the study was the analysis of the indications for, and assessment of the outcomes of secondary interventions after primary repair of injuries within the upper limb in the authors' institution - Department of General and Hand Surgery of the Pomeranian Medical University in Szczecin (a tertiary care unit).

Material and methods: Answers on questionnaires (including DASH) mailed to 33 patients were the subject of the analysis. The group consisted of 27 men and 6 women, mean age 36 years, in whom secondary interventions were performed at a mean of 8 months after primary surgery.

Results: Injuries were grouped in five categories: tendon lacerations, hand or finger amputations, nerve sections, complex tissue injuries, and isolated finger fractures. The most common cause of secondary intervention was incomplete finger movement and lack of opposition of the thumb. The most common operations included tenolysis, arthrolysis and opponensplasty. The outcomes of secondary surgery from patients' perspective were overall good: 13 (39\%) patients reported significant improvement, $16(48 \%)$ moderate, and only $4(13 \%)$ patients had no benefit. Twenty-five patients regained full, or almost full hand function (DASH scores $2-39)$, and 8 (24\%) had moderately to severely impaired function (DASH 40-80). Twenty-eight patients returned to work.

Conclusions: Primary repair of upper limb injuries (even severe) in the tertiary institution was adequate, and secondary interventions rarely necessary. The most common
\end{abstract}

indication was incomplete finger movement caused by ineffective postoperative mobilization. The important role of rehabilitation for the final outcome of the treatment of hand injuries was emphasized.

K e y w o r d s: hand injuries - secondary surgery - rehabilitation.

\section{Streszczenie}

Wstęp: Celem pracy była analiza wskazań do oraz ocena wyników wtórnych operacji kończyny górnej po pierwotnym zaopatrzeniu urazów w obrębie kończyny górnej w Klinice Chirurgii Ogólnej i Chirurgii Ręki Pomorskiego Uniwersytetu Medycznego w Szczecinie (ośrodek referencyjny).

Materiat i metody: Materiał do analizy stanowiły odpowiedzi udzielone przez 33 chorych na wysłane do nich pocztą kwestionariusze, w tym standaryzowany DASH. W grupie było 27 mężczyzn i 6 kobiet (średnia wieku 36 lat), a czas od pierwszej do wtórnej operacji wynosił średnio 8 miesięcy.

Wyniki: Obrażenia, z powodu których wykonano wtórne operacje, ujęto w 5 kategorii: uszkodzenia ścięgien, amputacje ręki i palców, uszkodzenia nerwów, urazy wielotkankowe i izolowane złamania palców. Najczęstszymi wskazaniami do wtórnych operacji była niepełna ruchomość palców i brak opozycji kciuka, a najczęściej wykonywanymi operacjami były tenoliza, artroliza i odtworzenie opozycji kciuka. Wyniki leczenia w ocenie pacjentów były ogólnie 
dobre: 13 (39\%) chorych oceniło poprawę jako znaczną, 16 jako umiarkowaną (48\%), a tylko 4 (13\%) nie uzyskało żadnej poprawy. Dwudziestu pięciu (76\%) chorych odzyskało pełną lub prawie pełną sprawność ręki (DASH 2-40 pkt), a 8 (24\%) miało umiarkowanie lub znacznie upośledzoną (DASH 40-80 pkt). Dwudziestu siedmiu (82\%) chorych wróciło do pracy.

Wnioski: Pierwotne zaopatrzenie nawet ciężkich urazów kończyny górnej w ośrodku referencyjnym było dobre, a wtórne operacje - rzadko konieczne. Najczęstszym wskazaniem była upośledzona ruchomość palców spowodowana nieskutecznym usprawnianiem pooperacyjnym. Podkreślono istotną rolę prawidłowej rehabilitacji pooperacyjnej dla końcowego wyniku leczenia obrażeń ręki.

H a s ł a: urazy ręki - wtórne operacje - rehabilitacja.

\section{Wstęp}

Nawet prawidłowe, zgodne z zasadami zaopatrzenie urazu kończyny górnej nie oznacza optymalnego wyniku leczenia. Zależy on od kilku czynników, m.in. rodzaju pierwotnego uszkodzenia i jego zaopatrzenia, przebiegu gojenia i skuteczności rehabilitacji pooperacyjnej. Przykładem może być wynik czynnościowy zszycia ścięgna zginacza po jego przecięciu, który zależy od mechanizmu urazu, techniki operacyjnej, gojenia rany i przebiegu usprawniania. Wykładnikiem wyniku leczenia jest pełna lub niepełna ruchomość palca. Jeżeli wynik leczenia nie jest optymalny, tzn. pozostaje jakiś deficyt ruchomości, czucia lub ogólnej sprawności ręki, rozważa się zwykle trzy warianty postępowania:

a) dalszą rehabilitację,

b) wtórną operację w celu poprawy istniejącego deficytu, który nie poddaje się rehabilitacji,

c) pozostawienie pacjenta $\mathrm{z}$ ubytkiem, aby przystosował się do niego, ponieważ ani dalsze usprawnianie, ani operacja nie dają nadziei na poprawę.

W piśmiennictwie nie ma wielu informacji o tym, jakie są przesłanki do podejmowania decyzji co do sposobów postępowania $[1,2,3]$. Niekiedy są one oczywiste, np. brak ruchomości palca po zszyciu ścięgna jest wskazaniem do leczenia operacyjnego - tenolizy lub wtórnej rekonstrukcji, a po złamaniu - do artrolizy. Podobnie brak czynności nerwu po jego zszyciu, choć w tym przypadku zakres metod leczenia jest szerszy i nie obejmuje tylko wtórnej rekonstrukcji nerwu, ale operacje na ścięgnach poprawiające czynność palców, np. odtworzenie opozycji kciuka lub korekcję ,szponiastości” [4, 5]. Decyzja o dalszej rehabilitacji, operacji lub zaniechaniu działań powinna opierać się na racjonalnych przesłankach, które niestety nie są jednoznacznie określone. Efekty po wtórnych zabiegach są najczęściej dobre, jednak część autorów wskazuje na $10-20 \%$ chorych, którzy nie uzyskują żadnej poprawy, a nawet pogorszenie $[1,2,6]$.
Celem pracy była analiza wskazań do oraz ocena wyników po wtórnych operacjach po pierwotnym zaopatrzeniu urazów w obrębie kończyny górnej wykonanym w Klinice Chirurgii Ogólnej i Chirurgii Ręki Pomorskiego Uniwersytetu Medycznego w Szczecinie (KChOiChR PUM), która jest jednostką referencyjną dla leczenia takich urazów.

\section{Material i metody}

Analizą objęto chorych, którzy w okresie 2 lat (2012 i 2013 r.) mieli wykonywanie wtórne operacje po pierwotnym zaopatrzeniu urazów w obrębie kończyny górnej w KChOiChR PUM. Byli to pacjenci:

a) którzy mieli pierwotne urazy zaopatrzone prawidłowo,

b) u których przebieg pooperacyjny był niepowikłany (nie wystąpiły powikłania, np. zerwanie zszytego ścięgna),

c) u których z jakiegoś powodu wynik leczenia nie był optymalny.

Do analizy nie włączono osób leczonych z powodu defektów pourazowych po pierwotnym zaopatrzeniu w innych ośrodkach. Zidentyfikowano 55 takich pacjentów, do których wysłano listy zawierające 2 kwestionariusze: jeden z pytaniami dotyczącymi przebiegu leczenia, rehabilitacji, rodzaju ubytku będącego wskazaniem do wtórnej operacji i jej wyniku w ocenie chorego. Drugim był standaryzowany formularz DASH, który pacjent miał wypełnić samodzielnie.

Z 55 wysłanych kwestionariuszy uzyskano 33 (60\%) odpowiedzi, które stanowiły materiał do dalszej analizy. Dane dotyczące badanej grupy, okresów między urazem i wtórną operacją oraz między ostatnią operacją a badaniem zawarto w tabeli 1. Spektrum urazów, z powodu których wykonano wtórne operacje, było szerokie, od izolowanych złamań palców do replantacji ręki, co przedstawiono w tabeli 2.

\section{T a b e 1 a 1 . Charakterystyka badanej grupy}

\begin{tabular}{|c|c|}
\hline Parametr & \\
\hline Liczba osób objętych badaniem & 33 \\
\hline Płeć: mężczyźni/kobiety & $27 / 6$ \\
\hline Wiek & średnia 36 lat (zakres 19-61) \\
\hline $\begin{array}{l}\text { Czas od pierwszej } \\
\text { do drugiej/kolejnej operacji }\end{array}$ & $\begin{array}{l}\text { Średnio } 8 \text { miesięcy } \\
\quad(\text { zakres } 2-24)\end{array}$ \\
\hline $\begin{array}{l}\text { Czas od ostatniej operacji } \\
\text { do badania }\end{array}$ & $\begin{array}{l}\text { średnio } 11 \text { miesięcy } \\
\text { (zakres 6-20) }\end{array}$ \\
\hline
\end{tabular}

T a b e l a 2. Rodzaje pierwotnych urazów, po których wykonywano wtórne operacje

\begin{tabular}{lc}
\multicolumn{1}{c}{ Rodzaj urazu } & Liczba chorych \\
\hline Uszkodzenia ścięgien & $12(37 \%)$ \\
\hline Amputacje (replantacje) i zmiażdżenia & $8(24 \%)$ \\
\hline Uszkodzenia nerwów & $6(18 \%)$ \\
\hline Złożone urazy wielotkankowe & $5(15 \%)$ \\
\hline Złamania palców & $2(6 \%)$ \\
\hline
\end{tabular}


Wyniki analizowano w poszczególnych podgrupach, w zależności od rodzaju pierwotnego urazu. Ze względu na niewielką liczebność grup, nie weryfikowano ich statystycznie.

\section{Wyniki}

Wtórne operacje po uszkodzeniach ścięgien - 12 chorych

Dziesięciu chorych miało uszkodzenia ścięgien zginaczy, a 2 prostowników. Wskazaniem do operacji była niepełna ruchomość lub sztywność palców po pierwotnym zszyciu, przy czym czynność naprawianych ścięgien była zachowana. Siedmiu chorych uczęszczało na rehabilitację trwającą średnio 1,5 miesiąca, jednak bez istotnej poprawy. Wtórną operację wykonano po okresie od 2 miesięcy do 2 lat po pierwotnym zaopatrzeniu. U wszystkich chorych przyczyną dysfunkcji ścięgien były ich zrosty z tkankami otaczającymi, które uwolniono (tenoliza). U 3 chorych wszczepiono na śródręczu cewnik do ciągłego znieczulenia nerwu palcowego wspólnego zaopatrującego operowany palec, przez który pacjenci podawali sobie $1-2 \mathrm{~mL}$ bupiwakainy przed ćwiczeniami. Wyniki podano w tabeli 3. W subiektywnej, 3 -stopniowej skali, po średnio 11 miesiącach od operacji 4 chorych oceniło poprawę jako znaczną, 6 jako umiarkowaną, a 2 nie zauważyło żadnej poprawy. U większości chorych sprawność ręki w subiektywnej ocenie kwestionariuszem DASH była dobra (średnia $27 \mathrm{pkt}$ ), przy czym u 2 była umiarkowanie upośledzona (DASH 42 i 54). Dziesięciu chorych wróciło do pracy.

\section{Amputacje ręki i palców - 6 chorych oraz zmiażdżenie ręki -2 chorych}

Trzech chorych miało replantacje po amputacjach rąk na wysokości nadgarstka lub śródręcza, 2 - po amputacji kilku palców, z których replantowano jeden lub dwa, 2 -zmiażdżenie ręki, a 1 - amputację pojedynczego palca. Powody wtórnej operacji były różne: niepełna ruchomość lub przykurcz palców, brak opozycji kciuka i ubytek tkanek miękkich. Czas rehabilitacji wynosił średnio 6 miesięcy (zakres 2-12), a czas od pierwszej do kolejnej operacji średnio 5 miesięcy (zakres 3-14). Zakres wtórnych operacji $(n=1-5)$ : odtworzenie opozycji kciuka, tenoliza i/lub artroliza w obrębie palca o ograniczonej ruchomości, plastyka blizny, pokrycie ubytku tkanek płatem, artrodeza i amputacja dysfunkcyjnego palca.

Trzech chorych oceniło poprawę po operacji jako znaczną, 4 jako umiarkowaną, a 1 nie odczuł żadnej poprawy. Średnia punktacja DASH 38 świadczy o tym, że u większości chorych sprawność ręki była umiarkowanie upośledzona, przy czym 1 chory po replantacji palca środkowego odzyskał pełną funkcję reki $(\mathrm{DASH}=2)$, a u 2 chorych (1 po zmiażdżeniu ręki i 1 po replantacji dwóch z czterech amputowanych palców) była znacznie upośledzona (DASH 66 i 68). Zdumiewające jest, że w tej grupie ciężkich urazów aż 7 chorych wróciło do pracy po średnio ponadrocznym okresie niezdolności.

\section{Izolowane uszkodzenia nerwów - 6 chorych}

Trzech chorych miało uszkodzenie nerwu pośrodkowego, 2 łokciowego, a 1 obu tych nerwów. Powodami wtórnej operacji wykonywanej po okresie 6-10 miesięcy od pierwszej były: brak opozycji kciuka, ,szponiaste” ustawienie palców i dokuczliwe parestezje. Zakres operacji: neuroliza u 2 chorych, odtworzenie opozycji kciuka -2 oraz korekcja „szponiastości” za pomocą transferu pasm ścięgna zginacza powierzchownego palca serdecznego na pasma boczne aparatu wyprostnego - 2 .

Wszyscy chorzy ocenili poprawę po operacji jako znaczną, a czynność ręki w punktacji DASH była dobra (średnia 22 pkt), przy czym u 1 pacjenta była umiarkowanie upośledzona (DASH 40 pkt). Pięciu z 6 chorych wróciło do pracy po średnio rocznym okresie niezdolności.

\section{Zlożone urazy wielotkankowe $\mathbf{- 5}$ chorych}

Do tej grupy zaliczono urazy wielotkankowe, ale bez niedokrwienia ręki ani palców (nie amputacje). Dwóch chorych miało przecięte wszystkie struktury (ścięgna, naczynia i nerwy) w obrębie nadgarstka, co określa się jako spaghetti injury [5]. Dwóch miało rozległe rany szarpane grzbietowej strony śródręcza ze złamaniami otwartymi kości i uszkodzeniem ścięgien prostowników, a 1 rany szarpane czterech palców od strony dłoniowej, z uszkodzeniem ścięgien i nerwów palcowych. Powody wtórnej operacji były następujące: niepełna ruchomość lub przykurcz palców, brak opozycji kciuka, upośledzone czucie, brak zrostu kości i ubytek tkanek miękkich. Wtórne operacje $(\mathrm{n}=1-5)$ wykonywano po średnio 6 miesiącach (zakres 2-10) od pierwotnego zaopatrzenia i były to: odtworzenie

T a b e l a 3. Wyniki leczenia w zależności od rodzaju wyjściowego urazu

\begin{tabular}{lcccc}
\multicolumn{1}{c}{ Rodzaj uszkodzenia } & Liczba chorych & Punktacja DASH & Powrót do pracy & Okres niezdolności do pracy \\
\hline Uszkodzenia ścięgien & 12 & średnia 27 (2-54) & $10 / 2$ & średnio 4,5 miesięca (2-24) \\
\hline Replantacje & 8 & średnia 38 (2-68) & $7 / 1$ & średnio 15 miesięcy (6-36) \\
\hline Uszkodzenia nerwów & 6 & średnia 22 (2-45) & $5 / 1$ & średnio 12 miesięcy (6-18) \\
\hline Urazy złożone & 5 & średnia 38 (11-80) & $3 / 2$ & średnio 9 miesięcy (2-12) \\
\hline Złamania palców & 2 & 34 i 41 & 2 & 3 i 6 miesięcy
\end{tabular}


opozycji kciuka, tenoliza i/lub artroliza w obrębie palca, plastyka blizny, wtórne zespolenie kości oraz pokrycie ubytku tkanek płatem. Dwóch chorych oceniło poprawę jako znaczną, 2 jako umiarkowaną, a 1 nie miał żadnej poprawy. Średnia punktacja DASH 37 świadczy o umiarkowanie upośledzonej sprawności ręki, przy czym 1 chory po urazie typu spaghetti odzyskał prawie pełną funkcję ręki (DASH = 11), a u 2 była znacznie upośledzona (DASH 66 i 80). Trzech chorych wróciło do pracy po średnio 9 miesiącach niezdolności do niej.

\section{Zlamania palców - 2 chorych}

Dwóch pacjentów miało izolowane złamania paliczków bliższych palca V, które były operowane: jeden zespolono drutami K, a drugi śrubkami. W obu przypadkach przyczyną wtórnej operacji wykonywanej po 3 i 6 miesiącach była sztywność palca w stawie międzypaliczkowym bliższym (PIP). Operacje polegały na tenolizie ścięgien zginaczy palca i atrolizie stawu PIP, przy czym 1 choremu wszczepiono cewnik do ciągłego znieczulenia nerwu łokciowego. Obaj chorzy ocenili poprawę po operacji jako umiarkowaną, a czynność ręki w punktacji DASH była umiarkowanie upośledzona (34 i 41 pkt). Obaj chorzy wrócili do pracy.

\section{Dyskusja}

Pomimo że wtórne operacje po pierwotnych naprawach uszkodzeń w obrębie ręki są wykonywane często, informacji na temat ich skuteczności jest niewiele. W przypadkach niepełnego zaopatrzenia pierwotnego urazu lub wystąpienia powikłań pooperacyjnych wskazania do wtórnych operacji są oczywiste. Jeżeli jednak pierwotna naprawa uszkodzeń była wykonana w ośrodku referencyjnym (w założeniu optymalna), wtedy wtórne operacje są rzadziej potrzebne i wynikają z niepełnego powrotu funkcji uszkodzonych struktur. W okresie analizowanych 2 lat w ośrodku referencyjnym zaopatrzono 1047 chorych z urazami otwartymi w obrębie kończyny górnej (bez izolowanych złamań kości), których zidentyfikowano na podstawie kodów ICD-10: S54-58 i S64-68. Z tej liczby wtórne operacje wykonano tylko u $55(5,2 \%)$ chorych, co świadczy o dobrym poziomie zaopatrzenia pierwotnego.

Najczęściej wskazaniami do wtórnych operacji były niepełna ruchomość lub przykurcze palców $(\mathrm{n}=24 ; 73 \%)$ i brak opozycji kciuka $(n=8 ; 24 \%)$. Niepełna ruchomość palców wynikała ze zrostów ścięgien zginaczy z tkankami otaczającymi i z zesztywnienia stawów międzypaliczkowych, co w obu przypadkach było spowodowane nieodpowiednim usprawnianiem pooperacyjnym. Brak opozycji kciuka wynikał z niepełnej regeneracji części ruchowej nerwu pośrodkowego, przy czym wszyscy ci chorzy odzyskali zadowalające czucie, co nie uzasadniało wtórnej operacji nerwu, tylko mniej ryzykowny i skuteczniejszy zabieg na ścięgnach. Podobne były wskazania do korekcji „szponiastości” palców spowodowanej dysfunkcją części ruchowej nerwu łokciowego. Pozostałe wskazania były rzadsze i wynikały z charakteru urazów, np. ubytki tkanek i brak zrostu kości.

Wyniki wtórnych operacji były na ogół dobre: 13 (39\%) chorych oceniło poprawę jako znaczną, 16 (48\%) jako umiarkowaną, a tylko 4 (13\%) nie miało żadnej poprawy. Czterech $(12 \%)$ chorych miało znacznie upośledzoną czynność ręki (DASH > 60), 4 umiarkowanie upośledzoną (DASH 40-60), a u 25 (76\%) sprawność ręki była pełna lub tylko nieznacznie mniejsza. Dwudziestu siedmiu (82\%) chorych wróciło do pracy, choć nie wszyscy do wcześniej wykonywanej. Należy podkreślić dobre wyniki po najcięższych obrażeniach ręki, jakimi są amputacje, zmiażdżenia i urazy wielotkankowe. U 9 (27\%) pacjentów wykonano 2-5 operacji wtórnych i byli to chorzy po najcięższych urazach. Przykładowy zakres takiej rekonstrukcji po replantacji śródręcza, to: pokrycie ubytku tkanek miękkich, tenoliza ścięgien, artroliza stawów międzypaliczkowych, odtworzenie opozycji kciuka i plastyka blizny skórnej.

Nieco dla kontrastu do analizy włączono 2 przypadki izolowanych złamań palca małego, które pierwotnie były leczone operacyjnie, co jest standardowym postępowaniem w praktyce KChOiChR PUM. Wynik po pierwszej operacji był niezadowalający z powodu zesztywnienia stawu PIP, a operacja wtórna przyniosła zwiększenie, choć nie odzyskanie pełnej ruchomości, co zostało ocenione przez chorych jako umiarkowana poprawa. Najbardziej zdumiewająca jest jednak ocena ubytku sprawności ręki oceniona na 34 i 41 pkt w skali DASH, co jest porównywalne z niesprawnością po amputacjach ręki lub urazach wielotkankowych, gdzie średnie wartości punktacji wynosiły 37 i 38 . To porównanie wskazuje na problem nie zawsze wiarygodnej oceny funkcji ręki w oparciu o kwestionariusz wypełniany przez samych chorych, co było wskazywane w piśmiennictwie [7].

Wtórne operacje po replantacjach palców są stosunkowe częste. W pracy Matsuzaki i wsp., 21 z 43 (49\%) pacjentów, w tym 39 z $70(56 \%)$ replantowanych palców wymagało operacji korekcyjnej lub rekonstrukcyjnej w okresie od 2 tyg. do 18 miesięcy od pierwotnego zaopatrzenia. Najczęściej wykonywano pokrycie ubytku skóry przeszczepem i tenolizę ścięgien zginaczy, rzadziej artrodezy stawu, osteotomie korekcyjne, wtórne zespolenia kostne lub plastykę blizny. Autorzy oceniają efekty operacji u większości chorych jako dobre [6]. W materiale $\mathrm{z}$ ośrodka referencyjnego wtórne operacje wykonano u 12 z 40 (30\%) chorych, w tym 16 z 59 (23\%) replantowanych palców, przy czym najczęściej były to tenolizy i wtórne rekonstrukcje ściegien; wyniki tych operacji oceniono także jako dobre [8].

\section{Wnioski}

Przedstawione wyniki pokazują, że pierwotne zaopatrzenie nawet ciężkich urazów kończyny górnej w KChOiChR 
PUM jest dobre, a wtórne operacje - rzadko konieczne. Najczęstszym wskazaniem jest upośledzona ruchomość palców spowodowana zwykle nieskutecznym usprawnianiem pooperacyjnym. Właściwa rehabilitacja po leczeniu obrażeń ręki ma duże znaczenie dla końcowego wyniku leczenia $[1,4,5]$. Niestety, ocena rehabilitacji przez większość pacjentów z analizowanej grupy była mierna, co wskazuje na konieczność poprawy tej części leczenia pooperacyjnego.

Niniejsza praca ma dwa mankamenty - brak oceny czynnościowej przed wtórną operacją, co uniemożliwiło obiektywną ocenę uzyskanej poprawy, a także metodykę badań opartą na kwestionariuszu wysyłanym do chorych, bez ich badania klinicznego. Z pewnością badanie kontrolne chorych z użyciem instrumentów pomiarowych (goniometr, dynamometr) pozwoliłoby na bardziej wszechstronną ocenę uzyskanych wyników, jednak uzyskane wyniki są wiarygodne, a praca ma walor poznawczy, zwłaszcza zważywszy na ubogość piśmiennictwa w tym zakresie.

\section{Piśmiennictwo}

1. Rosberg H.E., Carlsson K.S., Dahlin L.B.: Prospective study of patients with injuries to the hand and forearm: costs, function and general health. Scand J Plast Reconstr Surg Hand Surg. 2005, 39, 360-369.

2. Trybus M., Lorkowski J., Brongel L., Hladki W.: Causes and consequences of hand injuries. Am J Surg. 2006, 192, 52-57.

3. Żyluk A., Janowski P.: Wyniki leczenia złożonych, wielotkankowych uszkodzeń rąk. Pol Przegl Chir. 2011, 83, 153-165.

4. Rosberg H.E., Carlsson K.S., Hojgard S., Lindgren B., Lundborg G., Dahlin L.B.: Injury to the human median and ulnar nerves in the forearm - analysis of costs for treatment and rehabilitation of 69 patients in southern Sweden. J Hand Surg. [Br] 2005, 30B, 35-39.

5. Weinzweig N., Chin G., Mead M., Gonzales M.: „Spaghetti wrist”: management and results. Plast Reconstr Surg. 1998, 102, 96-102.

6. Matsuzaki H., Kouda H., Maniwa K.: Secondary surgeries after digital replantation: a case series. Hand Surg. 2012, 17, 351-357.

7. Żyluk A., Piotuch B.: Zastosowanie kwestionariuszy w ocenie wyników leczenia w chirurgii ręki. Chir Narzadow Ruchu Ortop Pol. 2009, 74, 193-201.

8. Walaszek I., Żyluk A.: Long term follow-up after finger replantation. J Hand Surg Eur Vol. 2008, 33 (1), 59-64. 